\title{
Tugas Simulasi Mikro
}

Nama : I Ketut Purnayasa

NRP $\quad: 130118062$

$\mathrm{KP} \quad: \mathrm{A}$

EMAIL : : ketutagus777@gmail.com

Perkembangan teknologi informasi yang semakin cepat diikuti dengan perubahan ekomoni berbasis industri menuju ekonomi berbasis informasi mengakibatkan perubahan yang cukup signifikan terhadap proses bisnis dalam sebuah organisasi. Isu globalisasi ekonomi menambah peluang setiap organisasi untuk mengembangkan sayapnya lebih luas lagi bukan hanya dalam skala nasional namun juga internasional. Perkembangan teknologi informasi mengakibatkan sistem informasi menjadi sesuatu yang sangat penting bagi seorang pengambil keputusan dalam suatu organisasi. Sistem informasi dapat membantu sebuah organisasi untuk menemukan proses bisnis yang sesuai dengan tujuan atau output yang diinginkan oleh organisasi tersebut. Teknologi informasi yang semakin berkembang dengan cepat harus diimbangi dengan stratgei bisnis, strategi organisasi, dan strategi sitem informasi (segitiga strategi sitem informasi) yang mumpuni sehingga organisasi dapat menjdalankan roda organisasinya dengan baik. Salah satu dampak yang ditimbulkan akibat adanya teknologi informasi adalah perubahan pola kerja dalam organisasi 